\title{
Pengolahan Limbah Penggilingan Padi Menjadi Bioplastik menggunakan palstisizer Sorbitol
}

Kartika Udyani ${ }^{1}$, Krisnadi Rinto ${ }^{2}$, Yuni Handarni ${ }^{3}$

1,2,3 Jurusan Teknik Kimia, Institut Teknologi Adhi Tama Surabaya,

Jl. Arif Rahman Hakim No. 100 Surabaya, Indonesia-font size 11pt

\begin{tabular}{|c|c|}
\hline INFORMASI ARTIKEL & ABSTRACT \\
\hline $\begin{array}{l}\text { Tanggal penyerahan: } \\
26 \text { Maret } 2021\end{array}$ & $\begin{array}{l}\text { Research on the manufacture of bioplastics from bran is one of the efforts to } \\
\text { develop the development of environmentally friendly plastics because they can be } \\
\text { decomposed by microorganisms. In addition, this study also seeks to reduce }\end{array}$ \\
\hline Tanggal diterima: & environmental pollution due to the disposal of rice mill waste. The research was \\
\hline 31 Maret 2021 & $\begin{array}{l}\text { conducted by mixing rice bran with water, sulfuric acid and sorbitol in various } \\
\text { variations of the ratio of sorbitol and bran } 1: 10 ; 2: 10 ; 3: 10 ; 4: 10 \text { and } 5: 10(v: b) \text {. }\end{array}$ \\
\hline $\begin{array}{l}\text { Tanggal terbit: } \\
28 \text { Juni } 2021\end{array}$ & $\begin{array}{l}\text { Furthermore, chitosan was added as a reinforcement with variations in the } \\
\text { addition of chitosan with bran, namely 4:10; 6:10; 8:10; 10:10 and 12:10 then } \\
\text { printed and analyzed for dance strength, swelling and surface morphology. The } \\
\text { test results showed the highest tensile strength value in the ratio of sorbitol and } \\
\text { bran 5:10 and chitosan bran 10:10 with the highest tensile strength value of } 64.27 \\
\text { MPa and 25\% swelling value. Surface morphology shows an uneven and hollow } \\
\text { surface. }\end{array}$ \\
\hline
\end{tabular}

\section{EMAIL}

${ }^{1}$ kudyani@itats.ac.id
Keywords: bran, sorbitol, bioplastic, tensile strength, swelling

\begin{abstract}
ABSTRAK
Penelitian pembuatan bioplastik dari bahan dedak merupakan salah satu upaya untuk pengembangan pembangan pembuatan plastik ramah lingkungan karena dapat diuraikan oleh mikroorganisme. Disamping itu penelitian ini juga berupaya untuk mengurangi pencemaran lingkungan akibat pembuangan limbah penggilingan padi. Penelitian dilakukan dengan pencampuran dedang dengan air, asam sulfat dan sorbitol pada berbagai variasi perbandingan sorbitol dan dedak $1: 10 ; 2: 10 ; 3: 10 ; 4: 10$ dan 5:10 (v:b). Selanjutnya ditambahkan kitosan sebagai penguat dengan variasi penambahan kitosan dengan dedak yaitu 4:10; 6:10; 8:10; 10:10 dan 12:10 lalu dicetak dan dianalisa kuat tari, swelling dan morfologi permukaan. Hasil pengujian menunjukkan nilai kuat tarik tertinggi pada perbandingan sorbitol dan dedak 5:10 dan kitosan dedak 10:10 dengan nilai kuat tarik tertinggi $64,27 \mathrm{MPa}$ dan nilai swelling 25\%. Morfologi permukaan menujukkan permukaan yang kurang rata dan berongga.
\end{abstract}

Kata kunci: dedak, sorbitol, bioplastik, kuat tarik, swelling,

\section{PENDAHULUAN}

Beras merupakan makanan pokok bagi sebagian besar masyarakat Indonesia. Untuk memenuhi kebutuhan akan makanan pokok tersebut maka di Indonesia banyak dijumpai tanaman padi. Pada proses pelepasan bulir padi dari batang padi akan dihasilkan buangan berupa jerami padi sedangkan pada proses pelepasan kulit padi melalui penggilingan hingga menjadi beras akan dihasilkan limbah berupa sekam dan dedak atau bekatul. Bekatul merupakan kulit ari beras dan pada proses penggilingan kulit ari akan terlepas. (Issara \& Rawdkuen, 2016). Pemanfaatan bekatul masih belum dilakukan secara optimal, mayoritas dari bekatul hanya dimanfaatkan sebagai pakan ternak saja. Pada setiap proses penggilingan padi dihasilkan bekatul 8-10\%, sekam 30\% dan beras sekitar 70\%. Di dalam bekatul terkandung karbohidrat yang cukup tinggi yaitu 53,29\%[1] Karena kandungan 
karbohidrat yang tinggi tersebut, maka bekatul digunakan sebagai bahan baku dalam pembuatan bioplastik. Dengan demikian pemanfaatan dedak untuk pembuatan bioplastik dapat digunakan sebagai alterntif untuk meningkatkan nilai ekonomi dedak.

Bioplastik merupakan plastik yang terbuat dari bahan alam yang memiliki sifat mudah terurai oleh mikroorganisme.[2] Dalam kehidupan sehari-hari plastik banyak sekali manfaatnya antara lain sebagai kemasan makanan, pembungkus berbagai macam kebutuhan rumah tangga seperti gula, beras, kopi dll. Disamping itu plastik juga digunakan dapat digunakan sebagai kantong belanja, sampul buku dan masih banyak lagi. Karena banyaknya kegunaan plastik maka kebutuhkan plastik semakin meningkat dengan semakin meningkatnya jumlah penduduk Indonesia. Apabila plastik yang digunakan untuk memenuhi berbagai macam kebutuhan berbahan polimer sintetis, maka akan menimbulkan permasalahan lingkungan karena tidak dapat diuraikan oleh mikroorganisme. Salah satu upaya untuk mengatasi permasalahan lingkungan karena penumpukan sampah plastik adalah dengan mengembangkan pembuatan plastik dari bahan yang dapat diuraikan oleh mikroorganisme yaitu bioplastik atau palstik biodegradable.[3]

Beberapa penelitian telah dilakukan dalam upaya pengembangan pembuatan bioplastik antara lain pengaruh penggunaan Asam Sulfat pada hidrolisa dedak untuk pembuatan plastik biodegradable.[1]. Pembuatan plastik biodegradable juga dibuat dari campuran dedak dan jagung [2]. Penelitian plastik biodegradable dari bahan umbi talas telah dilakukan dengan proses melt interkalasi [3] Penelitian polyester bioplastik dari bahan limbah pertanian dilakukan untuk mengetahui karakteristik bioplastik [4]. Penelitian pengembangan bioplastik menggunakan bahan umbi ganyong dilakukan menggunakan variasi selulosa asetat dan sorbitol [5]. Penelitian pembuatan bioplastik telah dilakukan menggunakan bahan nasi aking dan tepung tapioka dengan pastiziser gliserol[6]. Bahan lain yang digunakan dalam penelitian terdahulu untuk pembuatan bioplastik adalah sorgum[7]. Pengembangan penelitian pembuatan bioplastik berbahan pati kentang telah dilakukan menggunakan plastiziser gliserol[8].

Pada penelitian ini dilakukan pembuatan bioplastik dari dedak menggunakan plastiziser sorbitol dan bahan tambahan kitosan pada berbagai variasi perbandingan dedak dan sorbitol serta perbandingan kitosan dan dedak untuk mengetahui pengaruh perbandingan terhadap karakteristik bioplastik, uji swelling, uji kuat tarik dan morfologi permukaan.

\section{METODE}

\section{Bahan Penelitian}

Penelitian ini menggunakan dedak yang berasal dari Magetan, sorbitol, aquades, dan kitosan

\section{Peralatan penelitian}

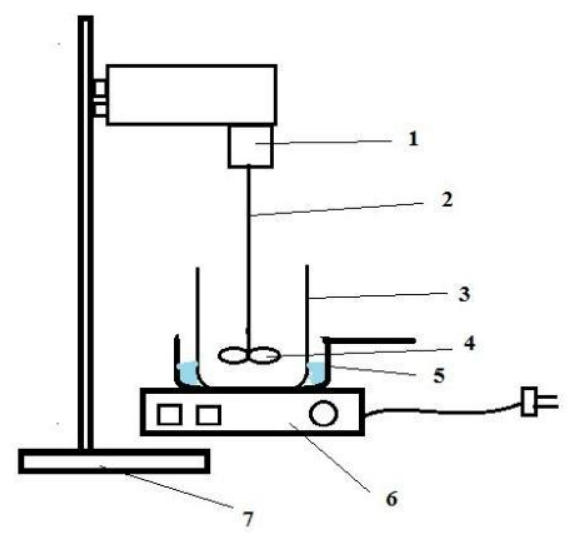

Gambar 1. Peralatan pembuatan bioplastik 


\section{Keterangan: \\ 1. Motor Listrik \\ 2. Batang Mekanik \\ 3. Beaker glass \\ 4. Impeller \\ 5. Panci \\ 6. Hot plate \\ 7. Statif \& Klem}

\section{Metode Penelitian}

Penelitian pembuatan bioplastik berbahan dedak diawali dengan pengecilan ukuran dedak dari penggilingan padi lalu diayak menggunakan ayakan 200 mesh. Selanjutnya dedak dicampur dengan air dengan perbandingan bekatul: air 1: $12,5 \mathrm{~m} / \mathrm{v}$. Kemudian dedak yang telah dicampur dengan air ditambah dengan asam asetat sebanyak $1 \% 7,5 \mathrm{ml}$ dilanjutkan dengan pemanasan pada suhu $65^{\circ} \mathrm{C}$ selama 15 menit. Campuran ditambahkan sorbitol sebagai plasticizer dan perbandingannya dengan bekatul sebanyak 1:10; 2:10; 3:10; 4:10 dan 5:10 (v:b). Tahap selanjutnya ditambahkan kitosan sebagai penguat dengan variasi penambahan kitosan dengan dedak yaitu 4:10; 6:10; 8:10; 10:10 dan 12:10. Sebelum ditambahkan kitosan dilarutkan terlebih dahulu dalam asam asetat $1 \%$ sebanyak $100 \mathrm{~mL}$. Selanjutnya campuran diaduk berkecepatan $\pm 320 \mathrm{rpm}$ dan dipanaskan pada suhu $65^{\circ} \mathrm{C}-70^{\circ} \mathrm{C}$ selama 60 menit. Produk hasil pencampuran dan pemanasan lalu dicetak di atas cetakan kaca dan diratakan untuk didapatkan lembaran plastik yang diinginkan. Hasil cetakan didiamkan pada suhu ruang dan dibiarkan hingga kering (sekitar 2-3 hari). Setelah kering, bioplastik dilepas dari cetakan untuk selanjutnya dilakukan pengujian berupa uji swelling, uji kuat tarik,dan uji morfologi.

\section{HASIL DAN PEMBAHASAN}

\section{Pengaruh perbandingan Sorbitol dan dedak terhadap uji kuat tarik bioplastik}

Pada penelitian pembuatan bioplastik digunakan sorbitol sebagai plasticizer. Untuk mengetahui pengaruh penambahan Sorbitol maka pada penelitian ini digunakan variasi perbandingan sorbitol dan dedak. Hasil uji kuat tarik pada variasi perbandingan plasticizer dan dedak dapat dilihat pada Gambar 2.

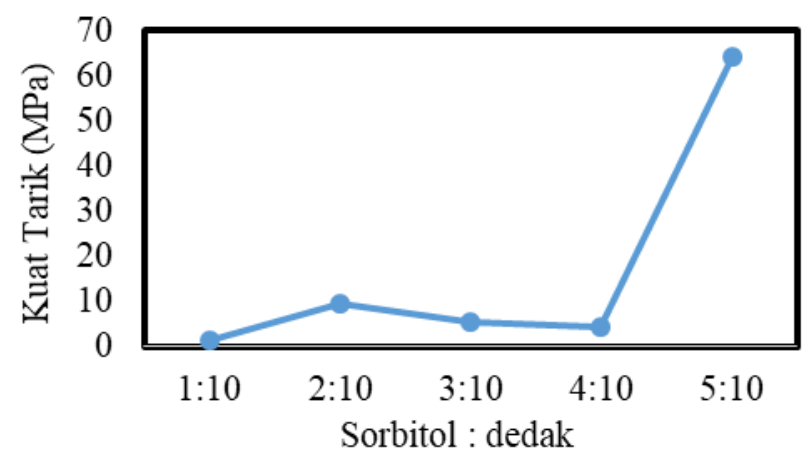

Gambar 2. Pengaruh perbandingan Sorbitol dan dedak terhadap uji kuat tarik

Berdasarkan Gambar 2 dapat diketahui bahwa pada rentang perbandingan Sorbitol dan dedak 1: 10 dan 2:10 terjadi kenaikan kuat tarik, tetapi pada rentang 2:10 sampai 4:10 terjadi penurunan kuat tarik. Pada rentang perbandingan sorbitol dan dedak 4: 10 dan 5:10 kuat tarik bioplastik mengalami kenaikan. Hasil uji kuat tarik bioplastik dengan perbandingan sorbitol dan dedak 5:10 (b:b) memiliki kuat tarik paling tinggi yaitu 64,27 MPa. Gambar 4.14 menunjukkan penambahan plasticizer cenderung menurunkan nilai kuat tarik dari plastik biodegradable. Namun, pada perbandingan sorbitol dan bekatul 5:10 nilai kuat tarik mengalami kenaikan yang tinggi. Semakin tinggi konsentrasi sorbitol yang digunakan akan 
menurunkan kuat tarik edible film. Hal tersebut disebabkan karena sorbitol sebagai plasticizer dapat mengurangi energi yang dibutuhkan molekul untuk melakukan pergerakan sehingga kekakuannya menurun dan nilai kuat tariknya juga menurun. Penyimpangan nilai kuat tarik pada penambahan sorbitol 5:10 disebabkan karena campuran kurang homogen sehingga sorbitol kurang berinteraksi dengan bekatul dan mengurangi kekakuan bekatul. Selain itu, dengan adanya struktur molekul cincin sorbitol yang menghalangi penyisipan antar rantai yang menyebabkan kurang efektif dalam menghambat interaksi antara rantai polimer. Pada penelitian tentang pembuatan bioplastik dari bahan pati kulit ubi kayu menggunakan sorbitol pada penambahan $20 \%$ sorbitol dengan nilai kuat tarik 9,12 MPa [9]. Standar internasional kuat tarik untuk plastik LDPE adalah 0,0124-0,0152 MPa, plastik HDPE adalah 0,0317 MPa dan plastik PP adalah 0,04006 MPa. Dengan demikian pada penelitian ini menghasilkan plastik biodegradable dengan kuat tarik yang lebih baik.

\section{Pengaruh perbandingan sorbitol dan dedak terhadap uji Swelling}

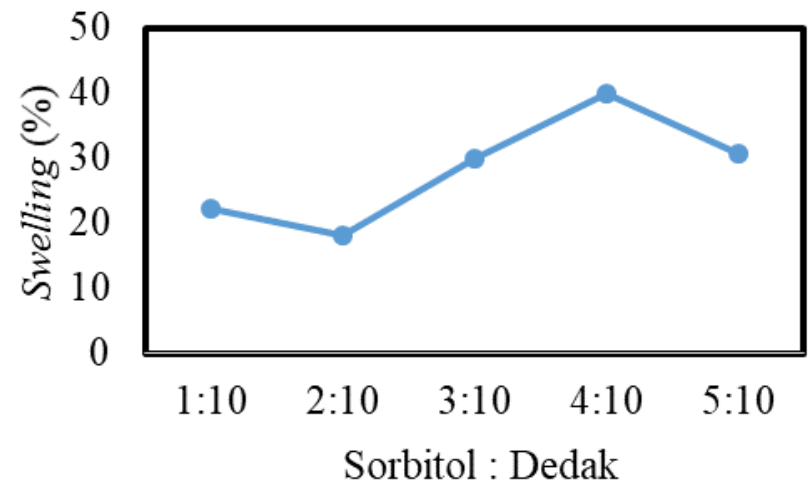

Gambar 3. Pengaruh perbandingan sorbitol dan dedak terhadap uji Swelling

Gambar 3 menunjukkan hasil uji swelling plastik biodegradable dengan variabel perbandingan plasticizer sorbitol dan dedak. Berdasarkan hasil penelitian diperoleh uji swelling terbaik diperoleh pada perbandingan 2:10 dengan persentase swelling 18,18\%. Gambar 3 menunjukkan penambahan jumlah sorbitol sebagai plasticizer cenderung menaikkan nilai penyerapan air. Hal ini menunjukkan bahwa bioplastik hasil penelitian ini memiliki sifat hidrofilik (suka air). Sifat ini dipengaruhi oleh penggunaan sorbitol yang bersifat hidrofilik sehingga mudah menyerap air. Pada penelitian pembuatan dan karakterisasi bioplastik dari pati biji alpukat-kitosan menggunakan sorbitol sebagai plasticizer mendapatkan hasil uji swelling terbaik pada penambahan sorbitol $1 \mathrm{~mL}$ sebesar $53,32 \%$ pada suhu $26^{\circ} \mathrm{C}$ dan $71,04 \%$ pada suhu $50^{\circ} \mathrm{C}$. SNI 7188.1-2016. Dengan demikian penelitian ini menghasilkan bioplastik dengan swelling yang lebih baik dibandingkan dengan bioplastik berbahan biji alpukat yang menggunakan plasticizer sama sorbitol namun belum memenuhi standar internasional[10] .

\section{Pengaruh Penambahan kitosan terhadap uji kuat tarik}

Pada pembuatan bioplastik dari dedak juga dilakukan pengujian kuat tarik, swelling untuk berbagai variasi perbandingan kitosan dengan dedak. Uji kuat tarik plastik biodegradable dari dedak padi dengan penambahan konsentrasi kitosan disajikan pada Gambar 4. 


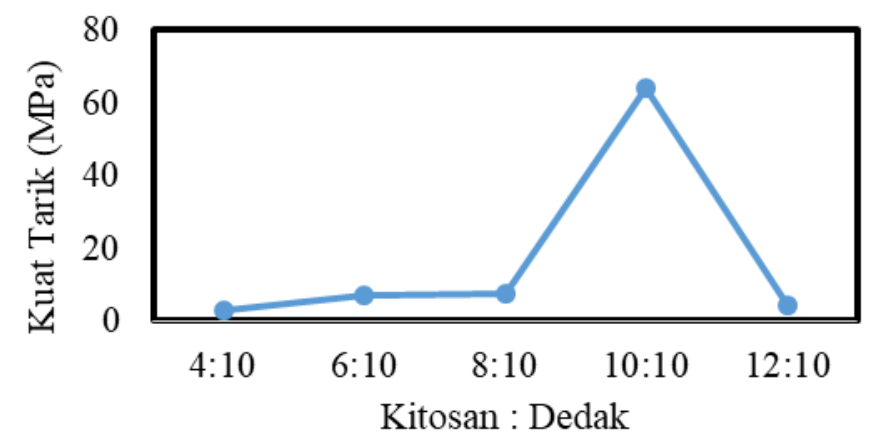

Gambar 4. Pengaruh penambahan kitosan terhadap uji kuat tarik

Pada Gambar 4. dapat diketahui pengaruh penambabhan kitosan pada pembuatan bioplastik terhadap kuat tarik. Hasil uji kuat tarik tertinggi diperoleh pada perbandingan 10:10 dengan nilai kuat tarik 64,27 MPa. Dari Gambar 4. dapat diketahui semakin banyak penambahan kitosan nilai kuat tarik bioplastik cenderung meningkat. Kenaikan kuat tarik disebabkan karena berkurangnya kandungan air pada bioplastik. Jadi struktur molekul pada bioplastik semakin rapat dan homogen yang menyebabkan kuat tarik semakin besar. Namun, pada perbandingan 12:10 nilai kuat tariknya menurun dan membuat plastik memiliki sifat rapuh. Kecenderungan pada penelitian ini sama dengan penelitian pembuatan bioplastik dari bahan pati kulit pisang kapok [11]. Tetapi nilai kuat tarik pada penelitian pembuatan bioplastik dari dedak ini memiliki kuat tarik lebih tinggi disbanding bioplastik berbahan pati pisang kapok yang memiliki kuat tarik $12 \mathrm{MPa}$. Dengan demikian penelitian ini menghasilkan plastik biodegradable dengan kuat tarik yang lebih baik.

\section{Pengaruh penambahan kitosan terhadap uji Swelling}

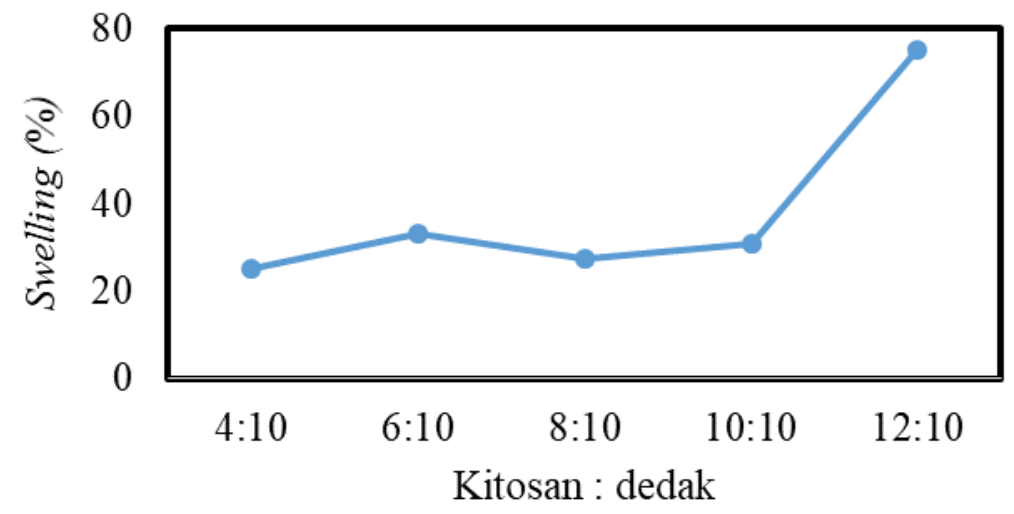

Gambar 5. Pengaruh penambahan kitosan terhadap uji Swelling

Hasil uji swelling pada pembuatan plastik biodegradable dengan variabel perbandingan kitosan dan dedak dapat dilihat pada Gambar 5. Berdasarkan hasil penelitian dapat diketahui bahwa dengan nilai swelling terbaik diperoleh pada perbandingan kitosan 4:10 dengan persentase swelling sebesar $25,00 \%$. Gambar 5 menunjukkan bahwa penambahan kitosan dapat meningkatkan nilai swelling. Hal ini kurang sesuai dengan teori yang menunjukkan bahwa semakin banyak kitosan maka bioplastik semakin kecil prosentase swellingnya karena 
kitosan memiliki sifat tidak larut dalam air. Dengan demikian pada penelitian ini, kitosan belum memberikan sifat ketahanan air yang baik pada bioplastik dari dedak. Hal ini disebabkan karena komposisi yang kurang seimbang antara kitosan dan dedak sehingga kitosan tidak berinteraksi dengan baik dengan pati yang ada dalam bekatul dan kurang dapat mengurangi sifat hidofilik dari dedak. Hal ini dibutktikan pada penelitian ini lebih tinggi dibandingkan penelitian pembuatan bioplastik dari biji alpukat menggunakan sorbitol sebagai plasticizer pada penambahan kitosan 0,5:10 biji alpukat memiliki nilai swelling 10, 23\%[10].

\section{Uji morfologi permukaan bioplastik}

Uji morfologi dimaksudkan untuk mengetahui bentuk morfologi permukaan bioplastik dan mengetahui penyebaran partikel pada permukaan bioplastik. Pada penelitian ini uji morfologi permukaan dilakukan dengan menggunakan SEM (Scanning Electron Microscopy) jenis SEM JEOL JSM 6510 LA di Labolatorium Terpadu Universitas Diponegoro. Adapun produk bioplastik yang diuji adalah bioplastik dengan variasi perbandingan sorbital dengan dedak 5:10 dan penambahan kitosan 10:10. Hasil uji SEM disajikan pada Gambar 6.

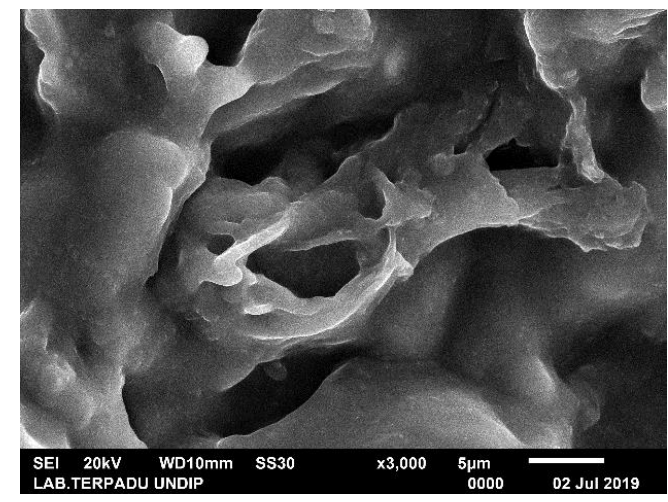

Gambar 6 Morfologi permukaan bioplasik

Gambar 6 menunjukkan terdapat ruang kosong dan rongga pada permukaan plastik. Hal ini disebabkan karena adanya gelembung udara. Gelembung udara dapat disebabkan karena plastik biodegradable tidak tergelatinisasi sempurna. Plastik tidak mengalami gelatinisasi sempurna dapat disebabkan karena pengadukan, waktu dan suhu pengeringan yang kurang sesuai. Selain itu, permukaan plastik yang tidak rata dapat disebabkan karena proses pencetakan yang kurang sesuai. Adanya rongaa dan gelatinasi yang tidak merata juga terjadi pada penelitian pembuatan bioplastik dari umbi ganyong[5].

\section{UCAPAN TERIMA KASIH}

Ucapan terima kasih diucapkan kepada YPTS yang telah memberikan kesempatan kepada penulis untuk melakukan penelitian dan publikasi penelitian..

\section{KESIMPULAN}

Berdasarkan penelitian yang telah dilakukan dapat disimpulkan bahwa semakin banyak penambahan plasticizer sorbitol akan menaikkan persentase swelling dan elongasi, menurunkan kuat tarik dan persentase degradasi dari bioplastik. Perbandingan kitosan dan bekatul mempengaruhi karakteristik bioplastik dimana semakin banyak penambahan kitosan 
akan menaikkan persentase swelling dan uji kuat tarik dari bioplastik . Kuat tarik tertinggi adalah 64,27 MPa dan nilai swelling terbaik adalah 25\%. Hasil analisa morfologi dilakukan pada bioplastik pada perbandingan sorbito dan dedak 5:10 (v:b) serta penambahan perbandingan kitosan dan dedak 10:10 (b:b) menghasilkan permukaan yang kurang rata dan berongga.

\section{DAFTAR PUSTAKA}

[1] Y. Yustinah, U. H. Hasyim, A. B. Syamsudin, and ..., "Pengaruh Konsentrasi Asam Sulfat Pada Proses Hidrolisis Dedak Padi Menjadi Glukosa Untuk Pembuatan Plastik Biodegradabel," Pros. ..., pp. 1-5, 2018.

[2] S. R. Dewi, N. N. Chairunisa, and R. A. Nugrahani, "Pembuatan dan Karakterisasi Kelarutan dalam Air dan Biodegradibilitas Bioplastik dari Campuran Dedak PadiJagung."

[3] A. Melani, N. Herawati, and A. F. Kurniawan, "Bioplastik Pati Umbi Talas Melalui Proses Melt Intercalation (Kajian Pengaruh Jenis Filler, Konsentrasi Filler dan Jenis Plasticiezer)," Distilasi, vol. 2, no. 2, pp. 53-67, 2017.

[4] C. S. Wu, "Characterization and biodegradability of polyester bioplastic-based green renewable composites from agricultural residues," Polym. Degrad. Stab., vol. 97, no. 1, pp. 64-71, 2012.

[5] D. I. Lailyningtyas, M. lutfi, and A. M. Ahmad, "Uji Mekanik Bioplastik Berbahan Pati Umbi Ganyong (Canna edulis) dengan Variasi Selulosa Asetat dan Sorbitol," J. Keteknikan Pertan. Trop. dan Biosist., vol. 8, no. 1, pp. 91-100, 2020.

[6] A. C. Kumoro and A. Purbasari, "Sifat Mekanik Dan Morfologi Plastik Biodegradable Dari Limbah Tepung Nasi Aking Dan Tepung Tapioka Menggunakan Pemlastik Gliserol," Teknik, vol. 35, no. 1, pp. 8-16, 2014.

[7] Y. Darni, T. M. Sitorus, and M. Hanif, "Produksi Bioplastik dari Sorgum dan Selulosa Secara Termoplastik,” J. Rekayasa Kim. Lingkung., vol. 10, no. 2, pp. 55-62, 2014.

[8] Afiifah Radhiyatullah, Novita Indriani, and M. Hendra S. Ginting, "Pengaruh Berat Pati Dan Volume Plasticizer Gliserol Terhadap Karakteristik Film Bioplastik Pati Kentang," J. Tek. Kim. USU, vol. 4, no. 3, pp. 35-39, 2015.

[9] Maulida, M. Siagian, and P. Tarigan, "Production of Starch Based Bioplastic from Cassava Peel Reinforced with Microcrystalline Celllulose Avicel PH101 Using Sorbitol as Plasticizer," J. Phys. Conf. Ser., vol. 710, no. 1, 2016.

[10] F. Y. Syamsul Bahri, Amri Aji, “Jurnal Teknologi Kimia Unimal,” J. Teknol. Kim. Unimal, vol. 2, no. November, pp. 85-100, 2018.

[11] Y. E. Agustin and K. S. Padmawijaya, "SYNTHESIS OF CHITOSAN-PATI bioplastics Kepok Banana,” J. Tek. Kim., vol. 10, no. 2, pp. 40-48, 2016. 